\title{
The indigenous languages of ancient Sicily
}

\author{
Las lenguas indígenas \\ de la antigua Sicilia
}

\author{
Jonathan Prag \\ University of Oxford \\ jonathan.prag@classics.ox.ac.uk
}

\begin{abstract}
This paper provides a brief synthesis of the evidence and principal points of discussion concerning the indigenous languages of ancient Sicily. Traditionally, three indigenous languages (Sikel, Sikan, and Elymian) are identified in use in Sicily in the period between the seventh and fourth centuries BCE. The evidence is extremely fragmentary, and its study is additionally complicated by the absence of up-to-date systematic collection of the material. The evidence is listed and the key points of linguistic and graphic discussion are presented. The traditional separation of Sikel and Sikan had already been challenged in existing scholarship; this paper suggests, in line with recent work, that the existing assumptions about the separation of Elymian also deserve to be challenged, and that the traditional assumptions about material and/or ethnic cultural boundaries on the island are potentially misleading.
\end{abstract}

Keywords: Sicily. Sikel. Elymian. Sikan. Linguistics. Epigraphy.

Resumen: Este trabajo es una breve síntesis de los datos ciertos y principales puntos de discusión sobre las lenguas indígenas de la antigua Sicilia. Tradicionalmente, se identifican tres lenguas indígenas (sículo, sicano y élimo) en Sicilia en el período comprendido entre los siglos VII y IV a. C. Sus testimonios son muy fragmentarios. Su estudio se complica, además, por la ausencia de una recopilación sistemática y actualizada de ese material. Aquí se recaban esos testimonios y se presentan los puntos clave de discusión en los planos lingüístico y gráfico. La distinción tradicional entre sículo y sicano ya había sido cuestionada en estudios anteriores; en este trabajo se sugiere, en consonancia con las tendencias actuales, que debe cuestionarse la existencia independiente del élimo y que los supuestos tradicionales sobre los límites culturales materiales y/o étnicos en la isla son potencialmente engañosos.

Palabras clave: Sicilia. Sículo. Élimo. Sicano. Lingüística. Epigrafía.

Recepción: 30.09.2019 | Aceptación: 11.03.2020

Funding: This paper has made possible by a grant from the John Fell OUP Research Fund (University of Oxford) for the development of I.Sicily. 


\section{Introduction}

This chapter is concerned with the language(s) attested in use in Sicily in the period between the seventh and fourth centuries BCE, other than ancient Greek and Phoenician. Generally referred to as the non-Greek languages (anellenico in the mostly Italian literature on the subject), these are traditionally associated with the ethnic groups described in the (mostly much later) ancient sources as Elymian, Sikel and Sikan. The evidence for these languages is however extremely limited and their identification is bound up in the wider methodological problems of individuating identity and interpreting material culture. As will be apparent in the discussion which follows, it is effectively impossible to present any overview independently of current problems and future challenges. Two caveats are necessary: the author is not a specialist in linguistics, and the position adopted in this chapter is deliberately sceptical.

The fundamental challenge posed by the Sicilian material is that of limited evidence, which either serves to reinforce, or is insufficient to challenge long-standing assumptions. Most famously, the "Sicilian archaeology" of Thucydides 6.2-5 describes the situation of the island in the late fifth century BCE with the presence of Sikanoi from Iberia, who arrived as early settlers on the island, and who "still inhabit the western parts of Sicily"; Elymoi who were refugees from Troy and settled on the borders of the Sikanoi, founding the cities of Eryx and Egesta; and Sikeloi, an Italic people, who drove the Sikanoi into the west and south of the island, and who "even now still hold the central and northern parts of the island." These are the peoples described as preceding the Phoenician and Greek immigrants of the eighth century BCE and later. Needless to say, the later traditions about all three peoples and their origins are confused and conflicting and have long been the subject of extensive discussion. ${ }^{1}$ The existence of these distinct ethnic labels in the classical period is arguably confirmed by very limited epigraphic evidence. ${ }^{2}$ However, as is now well recognised, it is problematic in the extreme to assume that any such identity label can be unquestioningly mapped onto presumed or observed differences in any one or more of material culture, linguistic practice, or any other material

1 Pancucci 2006; Cusumano 2006; De Vido 2006 provide recent overviews of the Sikanoi, Sikeloi and Elymoi respectively; $c f$. Sammartano 1998 for a detailed analysis of the earliest ancient historiographic traditions.

2 IG XII.6.2.575 (Sikanoi in a dedication on Samos, $6^{\text {th }}$ cent. BCE); IG I3 291 (Sikeloi in the Athenian tribute lists, 427-424 BCE); IG $\mathrm{I}^{3} .12$ (Elymoi speculatively restored in the treaty between Athens and Halikyai, 418/7-416/5 BCE). 
or socio-cultural feature. ${ }^{3}$ In recent discussions of the archaeological evidence it has increasingly been recognised that patterns in the surviving material culture do not obviously correlate with the traditionally assumed boundaries either between Elymians and Sikans in the west, or between Sikans and Sikels further east on the island (notwithstanding the continued ubiquitous use of the labels in most discussions). ${ }^{4}$ Consequently, the assumed existence of these groups as anything more than transient socio-political identities must always be questioned.

In the case of the ancient languages, the only evidence in the literary sources for the use of a distinct language by any or all of these groups is, firstly, the generic use of the label barbaroi, in contrast with Hellenes (as in Thucydides 6.2.6-3.1 and 6.6.1); and, secondly, the tradition of the so-called "Sikel glosses". The latter is a collection of over 70 terms attributed by later sources to Sikeliotai or Sikeloi (but not Sikanoi, or Elymoi). ${ }^{5}$ However, it is frequently unclear if these are merely Sicilian Greek dialect words, and whether these words originate directly or indirectly from local, Italic, or other languages is generally unknowable (it should be noted that in the later Greek tradition, the application of the adjectives Sikeliotes and Sikelos is itself far from decisive on the question of ethnic distinctions). ${ }^{6}$ Consequently, almost all modern discussion of the indigenous languages (essentially since Schmoll 1958) has taken its starting point from the emerging epigraphic evidence.

It will be apparent, however, that there is an immediate risk of circularity in this process, if epigraphic texts are assigned to one of Sikel, Sikan, or Elymian on the basis of geographical division alone, when these divisions are themselves derived from the aforementioned traditions. If the epigraphic evidence were extensive, and provided substantial and conclusive evidence for the language(s) in question, this risk would quickly be overcome. Since this is not the case, and since the evidence is both inconclusive and not yet system-

3 MacDonald 1998 offers salutary observations on the risks inherent in assuming correlations between linguistic evidence and ethnicity.

4 See e.g. Albanese Procelli 2003, 23-24, on the general point; De Cesare 2009, 644, on the Elymians and the modern "sforzo costante di ricercare una "cifra di identità" per questo popolo ambiguo e sfuggente, che sempre più sembra confondersi, almeno nella cultura materiale, con altri popoli anellenici della Sicilia." Cf. Marchesini 2012, 95; Ampolo 2012,31 .

5 Full collection in Whatmough 1933, 449-477. Thucydides 6.4.5 on Zankle as the original

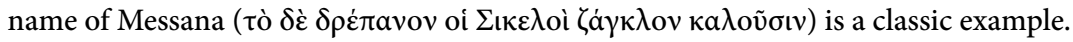

6 On the glosses, see Poccetti 2012, 65-70; on the use of the Sikeliote ethnic adjectives, see Prag 2013. 
atically assembled, the problem remains very much a live one. The gradual recognition of the problem is clearly demonstrated in the growing consensus that there is no basis, beyond the already mentioned literary tradition, to identify anything that survives as evidence for a Sikan language, distinct from Sikel. ${ }^{7}$ More than this, "The very fact that many inscriptions found in the Sikel area (but also in the Elymian area) can be classified either as "Sikel" tout court, or as "aberrant Greek", or as "hellenized Sikel", demonstrates that we are dealing with texts that do not allow of unequivocal attribution, and that ambiguity cannot always be accidental." It remains the case that almost all discussion continues to assume or imply a separation between Sikel and Elymian, and the poor availability of the published material exacerbates that situation. ${ }^{9}$ Only in the most recent discussions has there been a more visible tendency to treat Sikel and Elymian as potentially aspects of the same, less clear-cut phenomenon (thus, the parenthesis in the preceding quotation is unusual but also highly suggestive). ${ }^{10}$ Although it must for now remain the working position that Sikel and Elymian are indeed distinct languages, it is increasingly important that the nature of that relationship is questioned more closely, since there are linguistic features which appear to cross over any notional boundary, and comparable levels of linguistic variation can arguably be observed elsewhere across the island. ${ }^{11}$ Stated crudely, the discussion is increasingly shifting towards a productive emphasis upon the evidence of the epigraphic texts for linguistic and cultural interference between Greek and non-Greek speakers at the local and regional level, under a generic label of "non-hellenic" or "pre-Greek", with a particular emphasis upon the evidence of writing systems. ${ }^{12}$

7 E. g. Poccetti 2012, 51-55, who rationalises the problem by proposing a diachronic shift in usage of the terms Sikan (early) and Sikel (late) for essentially the same thing.

8 Tribulato 2015, 77 (my translation).

9 So, in a recent survey volume, Marchesini 2012 (Elymian) and Poccetti 2012 (Sikel).

10 Albanese Procelli 2003, 219-225, was already very suggestive; see especially Agostiniani 2012; Tribulato 2015.

11 Most obviously, the formulation of $e(i) m i$ + dative, implying an underlying linguistic tradition of dative of possession (see below).

12 Agostiniani 2012; Tribulato 2015 (see below). 


\section{The evidence}

As is implied in the preceding remarks, the available evidence for Sikel and Elymian is insufficient for conclusive assessments. Map 1 offers a necessarily schematic overview of the evidence, qualitative not quantitative, which aims to illustrate and support the following overview. The total number of inscribed objects is not large, but both limited publication and ambiguity of attribution mean that an accurate total is almost impossible (additionally, many "texts", especially those included in the Elymian corpus, are only single letters or symbols, and hardly texts at all): "Elymian" material numbers nearly 400 items, while Sikel material, which is even harder to quantify, due to the absence of any formal corpus, is nearer c. 50 .

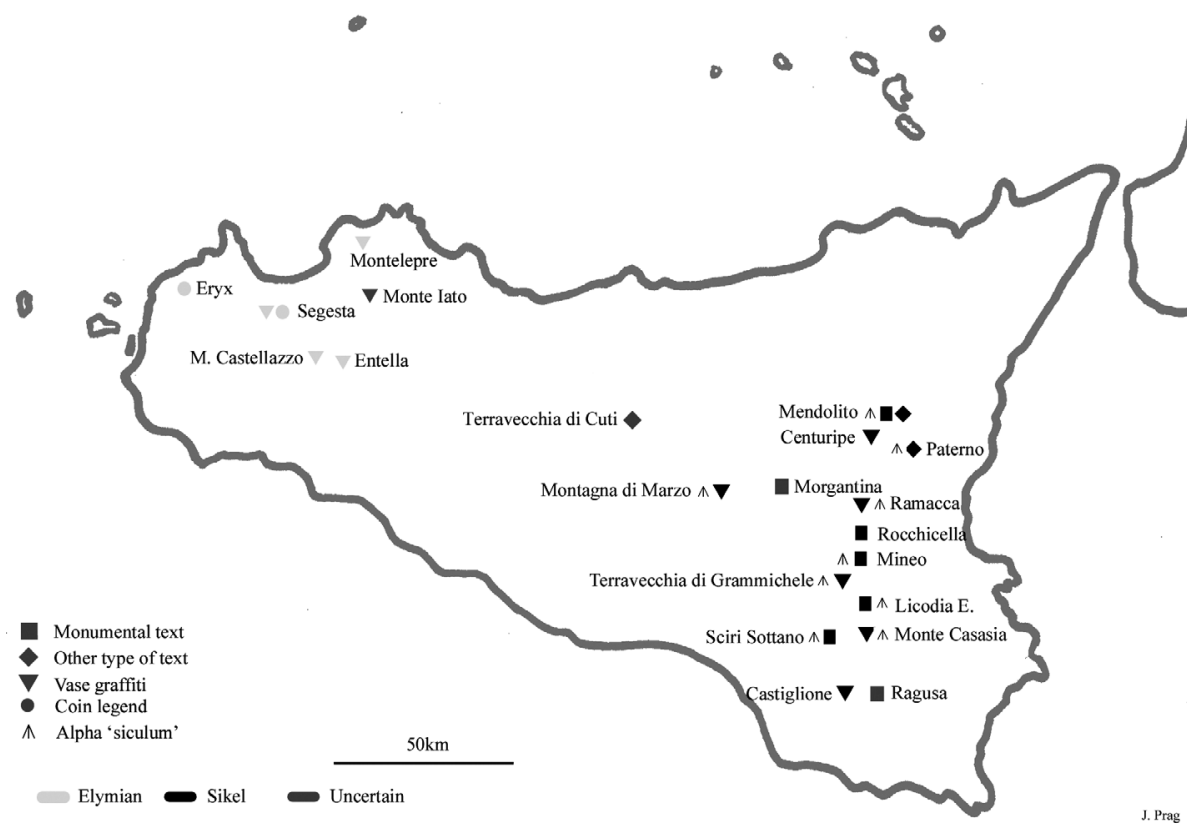

Map. 1. Distribution of indigenous language inscriptions in Sicily (by category and selected features).

Material that is usually described as Elymian consists firstly of coin legends from Segesta and Eryx, and secondly of vase graffiti (all incised, post-firing). The coin issues of Segesta begin c. 470 BCE, and continue until the early fourth century; those of Eryx begin slightly later, c. 460 BCE. The Segestan issues employ Greek letters, but from the earliest issues present a linguistically 
non-Greek legend (variously $\Sigma$ EГЕ $\Sigma$ TAZIB, $\Sigma$ ЕГЕ $\Sigma$ TAZIBEMI, $\Sigma$ EГЕ $\Sigma$ TAZIE, $\Sigma$ EГE $\Sigma$ TAZIA). From c. 410 BCE onwards a more familiar Greek genitive plural is found (ЕГE $\Sigma$ TAION / ЕГЕ $\Sigma T A I \Omega N$, both with and without initial $\Sigma$ ), sometimes on the opposite side of the same issue as the non-Greek forms. Chronologically, the reverse situation is visible on the Eryx coinage (Greek EPYKINON from c. 460, EPYKAZIB from c. 410 only). A single joint issue ( $\Sigma$ ETE $\Sigma$ TAION / EPYKINON) is attested in the mid-fifth century BCE. ${ }^{13}$ The ceramic material comes almost entirely from a site of secondary deposition: Grotta Vanella on the lower north-east slopes of Monte Barbaro, the principal hill of ancient Segesta (material seemingly dumped there in antiquity from higher up the hill). ${ }^{14}$ Most of the material was recovered between the $1950 \mathrm{~s}$ and 1980s, and the majority was united in the corpus of Elymian texts published by Luciano Agostiniani in 1977 (376 documents on 370 objects, out of which approximately half are "marks and sigla" rather than "texts"). A further c. 20 documents have subsequently been published in various articles. ${ }^{15} \mathrm{~A}$ total of four texts come from the Manico di Quarara necropolis near Montelepre (fig. 1), two from Entella, and one from Monte Castellazzo di Poggioreale. ${ }^{16} \mathrm{~A}$ fragment from Monte Iato has sometimes been counted among this material, but in this case the text is too fragmentary to allow of any certain attribution. ${ }^{17}$ The majority of the Elymian material has often been considered votive, but this is largely based on the original assumptions about the nature of the Grotta Vanella material as a votive deposit rather than as a secondary dump; the Montelepre material, which is very similar in form and content (graffiti on Attic black glaze vases), on the other hand all comes from funerary contexts - as does most of the Sikel material. The vases in question all belong to the very end of the sixth century or, predominantly, the first decades of the fifth century BCE, and most are Attic imports.

13 Hurter 2008, 35-39, is now the point of reference for the chronology, absolute and relative, of the legends, based upon a full die-study of the Segestan coinage; $c f$. Rutter 2013; 2016, 304-307; for a purely linguistic analysis, Simkin 2012, 176-179.

14 See De Cesare 2009 on the site of Grotta Vanella.

15 Agostiniani 1977; 1992; Camerata Scovazzo 1989; Biondi 1992; 1993; 1995; 1997; 1998.

16 Montelepre: Agostiniani 1977, nos. 283, 319 (here Fig.1); Ferreri 2012, 253; Tribulato 2017 (an abecedary). Entella: two very fragmentary texts, only speculatively attributable to "Elymian", Biondi 1993, no.10; Nenci, 1990, tav. 133.1. Monte Castellazzo: a fragment reading [-] tiaiem [-], Calascibetta 1990. 


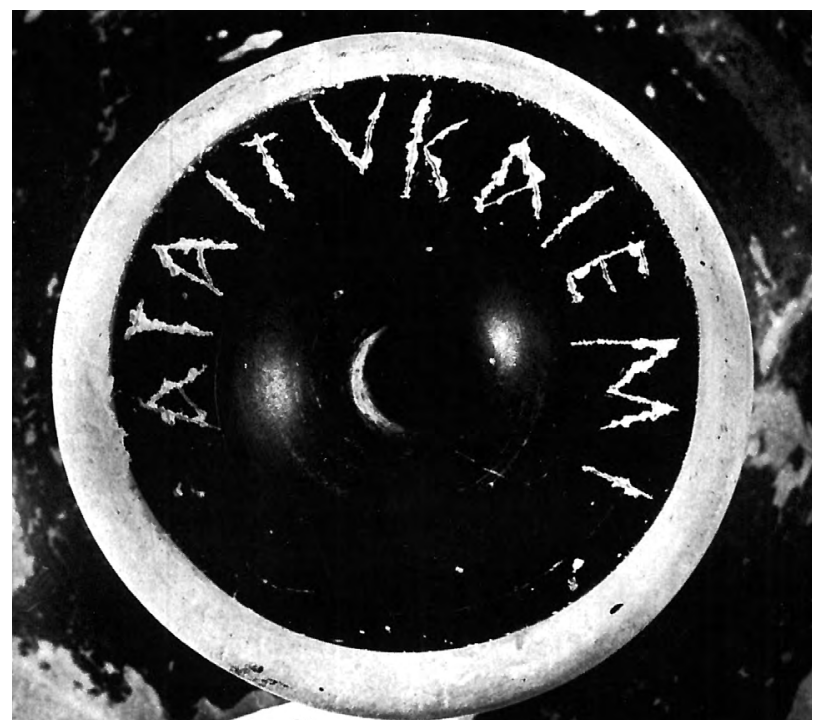

Fig. 1. Foot of a blackglaze Attic cup, $5^{\text {th }} \mathrm{c}$. BCE, Montelepre (from Agostiniani 1977: no. 319).

By contrast, the material traditionally classified as Sikel is much more diverse, both in typology and geographic distribution. It is also much harder to unite from existing publications. Other than the initial attempt to collect a body of epigraphic material by Ulrich Schmoll in 1958, which has been long outdated by the appearance of new evidence, the only subsequent coherent presentation of material is an appendix to a survey article published by Agostiniani in 1992, which gathered a selection of 27 texts from across the island, including Elymian material. ${ }^{18}$ In the absence of any systematic attempt to collect the material, existing discussions refer more or less allusively to texts, not all of which are fully published. Perhaps unsurprisingly, confusion is frequent, such as the emergence of what appears to be a false tradition of ceramic graffiti texts from Terravecchia di Cuti (seemingly confused with material from Terravecchia di Grammichele?), which in turn have been variously attributed to both the Elymian and Sikel regions, emblematic of the wider problems of attribution of short and fragmentary texts in such an uncertain overall context. ${ }^{19}$ It is not possible for this chapter to rectify that deficit, but a systematic

18 Schmoll 1958, cf. Agostiniani 1973 for an initial update; Agostiniani 1992 (cf. the briefer and more allusive survey of Cordano 2002).

19 Agostiniani 1992, 136, considers Terravecchia di Cuti as a distinct region in his survey (Agostiniani 2012, 144, instead groups it with Montagna di Marzo, without explanation), and alludes to "trois graffiti sur céramique", without further reference, alongside the well-known pyramidal loom-weights from the site (see below). Marchesini 2012, table 1, notes 3 Elymian texts at Terravecchia di Cuti without further discussion; Tribulato 2015, 65, follows Agostiniani 2012 in grouping Terravecchia di Cuti with Montagna di Marzo, 
corpus of all the archaic texts, which does not dogmatically separate Greek from possibly non-Greek texts, or indeed Elymian from Sikel, is an urgent desideratum if discussion is to advance significantly.

The Sikel material is now commonly grouped into three distinct geographic regions, determined primarily by the observed variation in the underlying Greek alphabets employed, deriving generally from the nearest major Greek foundation: the Etna region (i. e. Catania); the Hyblaean region (i. e. Megara Hyblaea and Syracuse); the Geloan hinterland / central Sicily. ${ }^{20}$ Broadly, the Sikel material dates to the sixth and first half of the fifth centuries BCE, although occasionally some texts push the limits of this periodisation. ${ }^{21}$ The activities of the Sikel leader Douketios in the mid-fifth century BCE are commonly taken to mark the final high point of Sikel identity and by implication the turning point for visibility of the language also. In contrast: contrast to the Elymian material, Sikel inscriptions include more or less monumental texts on stone and tile, as well as the more common vase graffiti (and occasionally texts painted on vases also). Consequently, the Sikel material also includes a number of moderately lengthy texts, providing a firmer basis for inferences about the underlying language(s).

and at 71 alludes (without reference) to "l'iscrizione NENDAS che compare su alcuni vasi da Terravecchia di Cuti", which must be a confusion with material from either Terravecchia di Grammichele or more likely Castiglione di Ragusa (cf. Agostiniani and Cordano 2002, 78-9 and 83-5).

20 The classification is fundamentally that of Agostiniani, first in Agostiniani and Prosdocimi 1976, 227, set out more fully, e. g., in Agostiniani 1992, 129-132, and most recently in Agostiniani 2012, 144; a slightly variant classification, separating the Camarina hinterland and the valley of the Margi from the Etna region is offered in Cordano 2002, 121-131.

21 E. g. Cordano 2012, 166, observes that the typology of tomb 15 at Coste di S. Febronia (Mineo), with Sikel texts on the walls, belongs in the seventh century BCE (there are however no grave goods, or other supporting evidence, to confirm such a high date). 
Monumental texts, broadly defined, come from a number of sites: ${ }^{22}$

- Mendolito (di Adrano): a monumental inscription from the city gateway; ${ }^{23}$ the so-called "cippo Sanfilippo"; ${ }^{24}$ a pair of inscribed tiles now argued to be from a monumental structure, rather than funerary texts; ${ }^{25}$ and a third fragmentary tile inscription. ${ }^{26}$

- Licodia Eubea: four funerary inscriptions on stone. ${ }^{27}$

- Sciri Sottano (10 km SW of Licodia): a funerary inscription on stone (fig. 2). ${ }^{28}$

- Coste di S. Febronia (territory of Mineo): two inscriptions on opposing walls of a rock-cut tomb. ${ }^{29}$

- Rocchicella (Paliké): an inscribed stone (now lost). ${ }^{30}$

- Also on stone, but of less certain status, are texts from Ragusa (a stone bearing traces of a moulding, with what appears to be a Sikel name) ${ }^{31}$ from Morgantina (a decorated stele, with an unresolved sequence of letters in the Greek alphabet); $;^{32}$ a fragmentary text from Taormina, which has sometimes been linked to the Sanfilippo cippus from Mendolito. ${ }^{33}$

$22 C f$. the rapid survey in Cordano 2012.

23 Agostiniani 2009a (Agostiniani 1992, no.1; ISic3364)

24 Manganaro 1961 (ISic3644).

25 Cultraro 2004 (Agostiniani 1992, nos. 2-3).

26 Agostiniani 1992, no.4.

27 Agostiniani 1992, nos. 11-13 (ISic3360, 3363, 3361), together with the additional text (ISic4391) recorded by Orsi (but noted as being unrecovered) in the inventory of the Museo Archeologico Regionale P. Orsi, Siracusa, supplementary to inv. no.41697 (Agostiniani 1992, no.12). A transcription and copy of Orsi's note is included in Paino 1958, without discussion. Agostiniani and Cordano 2002, 81-82, assert the existence of five published and three unpublished texts from Licodia, but in the ensuing discussion only reference two of these texts, while alluding to two more ( $c f$. similarly Cordano 2002, 122-123), and I can only individuate these four.

Agostiniani 1992, no.7 (ISic3362; here fig. 2).

29 Cordano 1999 (ISic3479, 3480).

30 Orsi 1900, 59 no.37 (Agostiniani 1992, no.10; ISic4394)

31 Cordano 2012, 167 (ISic3376).

32 Antonaccio 1999 (ISic2954).

33 Manganaro 1965, 163-165; Manganaro apud Agostiniani and Prosdocimi 1976-1977, 254; Cordano 2012, 169 (ISic4395). 
Fig. 2. Funerary inscription fron

Sciri Sottano, later $6^{\text {th }}$ or $5^{\text {th }}$ cent. BCE (ISic3362, Museo Archeologico

Regionale P. Siracusa, inv. 47071; photo J. Prag. With the permission of S. 39. Parco archeologico di Siracusa, Eloro e Villa del Tellaro;

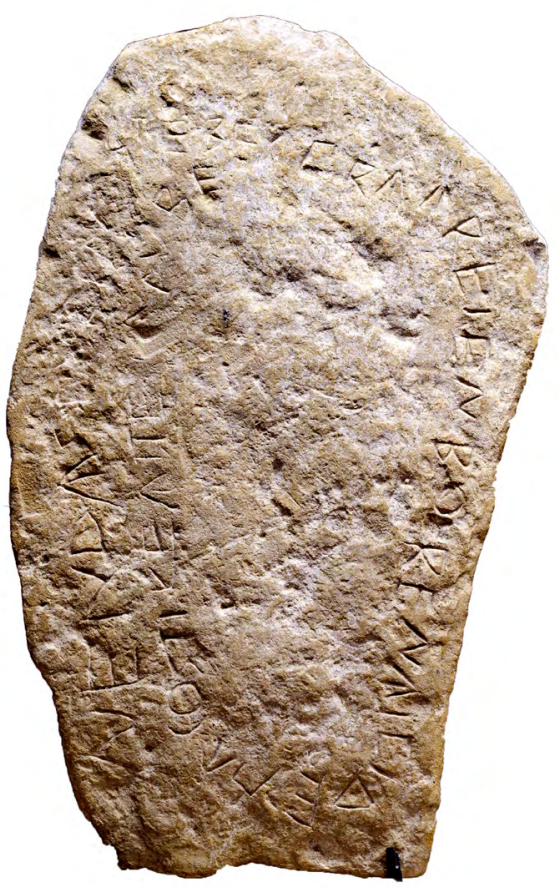
reproduction not permited).

The other material, with the exception of a small bronze statuette, possibly from the area of Mendolito, and tile-stamps from Paternò, is all on vases. ${ }^{34}$ Two of these are extended texts: the incised text on the famous askos from Centuripe; ${ }^{35}$ and a painted text on an amphora from Montagna di Marzo. ${ }^{36}$ The rest are short and/or fragmentary graffiti, from Montagna di Ramacca; ${ }^{37}$ Monte Casasia; ${ }^{38}$ Castiglione di Ragusa; ${ }^{39}$ Terravecchia di Grammichele

34 The bronze statuette recorded by Libertini 1923, is Schmoll 1958, no.20. The Paternò tile-stamps are in Pelagatti 1976-1977, 533-536 (Agostiniani 1992, no.6).

35 Agostiniani 1992, no.5.

36 Agostiniani 1992, no.18 (AA.VV., Kokalos 24 (1978), 3-65).

37 Two examples (both with alpha siculum), cited by Cordano 1993, 157 with n.20.

38 An incised ionic cup reading, perhaps: arelubalel, Cordano 1993, 156 no.2.

39 Three ionic cups, two reading nendas, one redorai emi: Cordano 1993, 155 no.1. 
(fig. 3$) ;{ }^{40}$ Morgantina $;{ }^{41}$ and Montagna di Marzo. ${ }^{42}$ In addition to this material, c. 20 inscribed pyramidal loom-weights are known from Terravecchia di Cuti, of much disputed interpretation (perhaps primarily anthroponyms, uncertainly of Greek or indigenous origin), but increasingly included within discussion of the Sikel language(s) and even occasionally Elymian. ${ }^{43}$

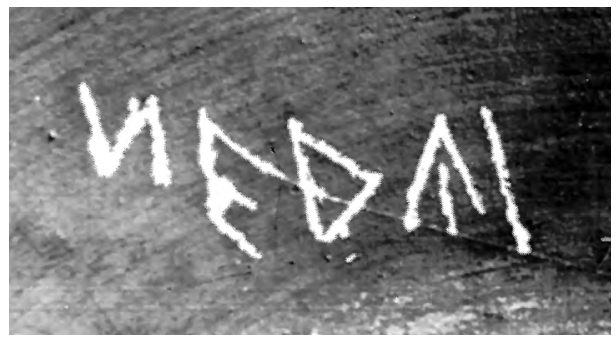

Fig. 3. Interior of a black-glaze Attic kylix, mid- $5^{\text {th }}$ c. BCE (Grammichele, Museo Comunale, inv. 3644; from Agostiniani and Cordano 2002, fig. 5).

\section{Points of discussion}

The fragmentary nature of the evidence renders impossible a detailed presentation of the linguistic features and writing systems of Sikel and Elymian, for the basic reason that the evidence is insufficient and many features remain either unknown or subject to ongoing debate. Discussion to date has focussed on the one hand around the linguistic attribution of the non-Greek language(s) of the island, and on the other around aspects of the writing systems employed. In the broadest terms, it is now possible to say that the material from eastern and central Sicily is increasingly treated as a relative-

40 A black-figure crater with a text ending in poterom (Agostiniani 1992, no.9), and two attic kylixes, reading nedai $(=n e(n)$ dai?, the initial $n u$ reversed; here fig. 3 ) and qupeipinigoiemi; all three in Agostiniani and Cordano 2002, 82-87.

41 A single Sikel text (pibe) on an Attic kylix, Lejeune 1990a; $c f$. Antonaccio and Neils 1995 for a Greek graffito, and Lyons 1996 (index, s.v. graffiti) for other single-letter graffiti. I can find no example of alpha siculum, although Agostiniani 2012, 152 states that it is present at Morgantina.

42 Twelve texts were published in Mussinano 1970 on vases from tomb 31 east (see now Agostiniani and Albanese Procelli 2015); further material (18 texts) was partially published by Crevatin 1975, republished with additional material (c.10 texts) by Manganaro 1999, 21-27, many of which are not securely Sikel. The exact number of non-Greek texts (and texts securely from Montagna di Marzo) is unclear. Agostiniani 2012, 145, speaks of "in totale un po' meno di novanta".

43 Cf. n.15 above; Agostiniani 1992, nos. 25-27; Brugnone 1993 is the fullest publication, presenting 17 weights, one of which is inscribed on four faces. 
ly coherent whole. At the same time the evidence displays not insignificant variation at both the linguistic and the palaeographic levels. Consequently, while there is a consensus that the underlying linguistic stratum has strong affinities with the Sabellic languages of central and southern Italy, visible at the morphological, lexical and onomastic levels, there remains considerable uncertainty whether one or more local languages underlies the evidence; with the Elymian evidence there is even less certainty. ${ }^{44}$ In part this is a function of the fact that lengthy texts are few - the longest texts, particularly those from Mendolito, have provided the most secure evidence for attribution, such as direct lexical parallels (e.g. touto- and akara-) and examples of binomial nomenclature which echo Italic forms (e.g. rukes hazsuie $[s]$ ). However, the onomastic landscape is itself unclear, with diverse examples of binomial and single names across Greek and native texts, and limited evidence for binomial forms in the Elymian material also, although single names are more common. ${ }^{45}$ The attribution of individual names to one or other linguistic (or ethnic) stratum is itself far from straightforward in this situation.

One particularly striking example of this complexity can be observed in the apparent use of a dative of possession. The most observable formulaic feature of the Elymian material is the existence of a termination in - $a i$, with or without the additional verbal element of emi (the substantial preponderance of $-a$ stems over other vowels such as $-o$ in the surviving onomastic material is itself a challenge, occasionally explained as a result of the assumed (female) votive context). This material appears closely to imitate the very familiar Greek type of "speaking inscription", e.g. "I am the kylix of...". This is obvious in the use of the verb emi, and it remains a subject of debate whether Elymian developed the form emi in parallel or borrowed the formulation wholesale from Greek practice. ${ }^{46}$ What is not in debate, however, is that the very limited Elymian corpus shows strong evidence for the use of what appears to be a dative of possession, even if borrowing the Greek verb emi, and this seems to be clearly reflected also in the coin legends from Segesta, which often match

44 Poccetti 2012, 77-85, provides a detailed summary of the key linguistic points; $c f$. Agostiniani 1992, 139-142 (concluding "on ne peut prouver, au moins pour l'instant, que les textes de l'aire sicule attestent tous la même langue"); for Elymian, Agostiniani 1990; 1992, 142-146; 2006 with updated references.

45 Agostiniani 2009b offers a detailed discussion of binomial naming across the material (with possible Elymian examples at 55-56, referencing Agostiniani 1977, nos. 319, 322); cf. Poccetti 2012, 84 .

46 See especially Agostiniani 1992, 143-46, favouring the latter; $c f$. Tribulato 2015, 72-73. 
the form $\Sigma$ ЕГЕ $\Sigma$ TAZIB with the familiar Greek genitive plural $\Sigma$ EГЕ $\Sigma$ TAION (the interpretation of the termination in -B as reflecting most likely a fricative labial such as $|f|$, and so constituting a dative plural, is here adopted; see further below). However, if the use of a dative of possession (and the borrowing of the Greek emi - and indeed the actual institution of coinage) is generally accepted for Elymian, it is also recognised to recur in both Greek and "Sikel" contexts on the island. Several texts from Gela display this non-standard (sometimes called "aberrant") use of the dative, most obviously in the text

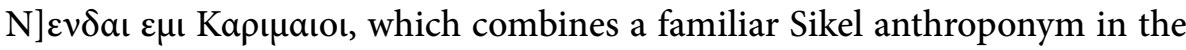
dative in an otherwise normal Greek text (alongside other examples of Greek names ending in the dative). ${ }^{47}$ Clear examples are visible in "Sikel" texts, such as one of the cups from Castiglione (redorai emi) and those from Terravecchia di Grammichele (ne(n)dai (= fig. 3) and qupei pinigoi emi), and perhaps implied in other texts with seemingly dative endings. ${ }^{48}$ The cultural intermixing implied here is clearly complex, but two observations can perhaps be made: firstly, the implications for Elymian would seem to be in favour of an Italic language (the dative construction, and the form of the dative endings, especially the likely fricative labial termination of the dative plural); $;^{49}$ but secondly that this is a pattern which seems to have a remarkably wide diffusion across the island, and so argues against accepting the traditional narrow limits of Elymian. To quote Agostiniani and Cordano, "nothing convinces us that this was not a trait that linked Elymian, in which it seems possible to see Italic characteristics, to the indigenous languages of eastern Sicily, in which the Italic characteristics are, - at least for some of these - quite clear".50

Integral to much of the linguistic analysis, and increasingly to the fore in recent analysis of cultural linguistics on the island in the archaic period, is

47 It is notable that these texts are usually discussed as anomalous Greek texts, rather than indigenous texts, presumably because they come from a Greek colonial site.

48 The fullest discussion is Agostiniani and Cordano 2002, 87-89. The Geloan material first analysed in Agostiniani 1980-81, 515-517, the text discussed here Manni Piraino 1980, no.40. The Castiglione cup, Cordano 1993, 155 no.1. The Terravecchia di Grammichele material, Agostiniani and Cordano 2002, 82-87. Agostiniani and Cordano 2002, 88, appear to create an additional text from Ragusa reading adaioi through conflation with the "unpublished" text from Licodia to which they also refer (reproduced after Orsi in Paino 1958 = ISic4391).

49 Agostiniani 1992, 146; cf. Poccetti 2012, 76.

50 Agostiniani and Cordano 2002, 89, "niente ci assicura che questo non fosse un tratto che accomunava l'elimo, in cui sembra di intravedere caratteristiche italiche, alle lingue indigene della Sicilia orientale, nelle quali i tratti italici sono - almeno per una parte di esse - del tutto evidenti" (my translation). 
the epigraphic use of particular alphabets across the island especially in the representation of the non-Greek languages. Underpinning the discussion is the fact that the contemporary Greek practice on the island was itself very diverse and fluid at this date, with divergent alphabets in use across the various Greek settlements. The argument is now well developed that the exact forms of the Greek alphabet in use across the island for the non-Greek languages closely reflect the influence of the neighbouring Greek cities in each case. ${ }^{51}$ On this approach, Elymian is situated (geographically and culturally) within a narrowly Selinuntine sphere of influence, whereas the diversity of practice visible across the Sikel material is reflected in the varying influence of Gela, Camarina, Syracuse, Megara Hyblaea and Catania.

Within these discussions, two particular features have traditionally dominated discussion: the variation in symbols for beta, and the so-called alpha siculum. The evolution in the interpretation of these features itself reflects the move towards more nuanced socio-linguistic readings of the evidence, and in turn paves the way for increasingly sophisticated analyses of this sort.

Within the Elymian evidence, a long-standing challenge has been posed by the presence of the "reversed $n u$ " symbol $\langle И\rangle$. At first glance this appears unproblematic for precisely the reason that the reversed $n u$ is the letter employed in place of standard beta $<\mathrm{B}>(/ b /)$ in the Selinuntine Greek alphabet, and is therefore consistent with the other evidence for the influence of the Selinuntine alphabet on the Greek letters employed in the Elymian language texts (such as four-barred sigma and open heta). The matter is, however, complicated by the repeated presence in Elymian texts, alongside the reversed $n u$ symbol, of the standard beta $<\mathrm{B}>$ as a letter. The presence of the same anthro-

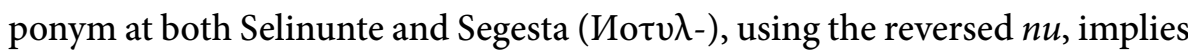
the same usage; the presence of the sequence АИГ $\triangle$ in an abecedary from Montelepre now seems decisive on this point. ${ }^{52} \mathrm{~A}$ greater debate has instead focused around whether the standard beta $<\mathrm{B}>$ also represents $/ \mathrm{b} /$ or a different

51 The model is explicit at Agostiniani 2012, 139 and 144, and spelled out further in Tribulato 2015, 63-65; on the Greek alphabets in Sicily, see especially now Brugnone 1995.

52 Jeffery 1990, 277 no.38c; Agostiniani 1977, nos. 289 and 317; Tribulato 2017. Marchesini 1998 , reiterated in 2012,109-110, has instead argued that the reversed $n u$ is merely a graphic error for standard $n u$ (the chronological seriation which Marchesini proposed - as outlined in 2012,104 - appears at risk of circularity given the nature of the dataset (e.g. the reversed $n u$ is presumably itself one of the features employed to generate the seriation) and assumes greater chronological precision is possible within a very few decades than seems reasonable). 
sound and, if so, what. Michel Lejeune argued, with some modification over time, that it represented a vocalic sound, but the presence of sequences such as -] $\tau$ бo $\beta \varepsilon\left[\right.$ - are very much against this. ${ }^{53}$ Luciano Agostiniani has persuasively argued that the likely trajectory is that of the Elymian language having a second labial sound, not greatly removed from $/ \mathrm{b} /$, such as a labial fricative /f/, not catered for by the standard Greek alphabet. ${ }^{54}$ Given the closeness of this second sound, the existence of the "standard" beta in other alphabets on the island would then have offered an obvious graph for use in its representation (and Syracusan influence is for example visible in the coin iconography). ${ }^{55}$ Such an interpretation opens the door, as already noted above, to the relatively straightforward interpretation of the forms $\Sigma$ EГE $\Sigma$ TAZIB and EPYKAZIB on the coinage as dative plurals, with clear implications for the Indo-European and possibly Italic — nature of the language. ${ }^{56}$

Additionally, it is worth noting the observation that the standard Greek letter beta $<\mathrm{B}>$ is more frequent in Sikel texts than one would expect for an Indo-European (and probably Italic) language. ${ }^{57}$ The generally accepted explanation for this is that in Sikel texts the letter $\langle\mathrm{B}>$ is in fact doing double duty for both the value /b/ and a fricative /f/. This contrasts with the situation just noted in Elymian, which writing system, through the appropriation of the non-standard Selinunte symbol $<$ $>$ for the sound $/ b /$, instead developed separate graphs for the two sounds. ${ }^{58}$ As with the use of dative endings discussed above, the implication is that Elymian is also an Italic language, in close relationship to the Sikel language(s). However, it should also be acknowledged that there is one apparent difference between the two areas, in that occlusive aspirates are present, albeit sporadically, in Elymian ( $p h i$ and $k h i$ ), but all three of phi, khi and theta are so far absent in the Sikel area, as evidenced by the


amphora inscription from Montagna di Marzo. ${ }^{59}$ Whether the combination of these features implies that we are dealing with linguistic variants of the same

53 Agostiniani 1977, no.297; Lejeune 1970; 1990 b.

54 Agostiniani 1990; 1992, 135-136.

55 Hurter 2008, 22; Rutter 2016, 305, on the coinage.

56 For the linguistic implications, Simkin 2012, 176-179.

57 Following Agostiniani 1992, 137.

58 Poccetti 2012, 78-79, after Agostiniani (e. g. 1992, 137, cf. Agostiniani 2012, 143).

59 For this and further examples see Agostiniani 1980-1981, 513-515; cf. Agostiniani 1992, 138; Poccetti 2012, 75. 
language, or greater divergence, is an open question and one that deserves to be pressed.

A rather different scenario emerges within the Sikel area, where there is substantial variation in the versions of the Greek alphabet employed, both at the local (e. g. between Mendolito and Centuripe) and at the regional level. Scholars have repeatedly mapped out these variations and in doing so defined at least three distinct regions of Sikel graphic variation: ${ }^{60}$ the Etna region, including Mendolito, Centuripe, Paternò, Rocchicella di Mineo (Paliké), and Montagna di Ramacca; the Hyblaean region, including Licodia Eubea, Ragusa Ibla, Sciri Sottano, Monte Casasia, Castiglione di Ragusa, Terravecchia di Grammichele, and Morgantina; and the central Sicilian region (or Gela hinterland), principally defined by Montagna di Marzo. These regions all show the influence of the primary Greek settlements in their alphabet, but, as has long been noted, there is one feature that is common to many of these texts and, in contrast to the other variations between these epichoric alphabets, largely cross-cuts these distinctions - the so-called alpha siculum ( $A$; cf. map 1 and fig. 3 ) ${ }^{61}$ What is now reasonably clear is that although this particular symbol is not universally present in texts identified as Sikel (it is, for instance, clearly absent in the Centuripe askos), it is widely used, and indeed has been argued to be a point of deliberate cultural choice in the case of texts in tomb 31 at Montagna di Marzo. ${ }^{62}$ In light of this, Agostiniani has suggested that the letterform might be seen to serve as an "affermazione della solidarietà interna alla compagine sicula e del parallelo antagonismo nei confronti dellelemento greco". ${ }^{63}$ This interpretation seems to be supported by the near total absence of the letter from texts which are recognisably Greek. ${ }^{64}$ On the other hand, it is far from being a ubiquitous symbol in texts identified as Sikel, and certainly is not by itself a defining feature of a "Sikel alphabet", which is by now recognised not to exist in any unitary form. ${ }^{65}$

60 See n.20 above.

61 See especially Agostiniani 1980-1981, 507-513.

62 Agostiniani 2012, 149-150, and in detail Agostiniani and Albanese Procelli 2016 (cf. Tribulato 2015, 65-68).

63 Agostiniani 2012, 148.

64 A single example is in fact known in the Elymian corpus (Agostiniani 1977, no.256), but as with several other texts in this corpus (e.g. several Attic texts), the inference which is usually drawn is that the writer (or indeed the vase itself) originated elsewhere, and not that the letter was also sometimes employed in Elymian. That inference is of course open to challenge.

65 Agostiniani 2012, 148-154. 


\section{Conclusion}

This brief, and necessarily partial, survey of the non-Greek languages of Sicily has deliberately refrained from attempting to map out systematically the linguistic features, or indeed alphabets of the languages in question. Given the currently very partial nature of our knowledge, the consequent limitations on our ability to draw firm conclusions about the linguistic basis of these languages, and the obvious impact of new evidence as it emerges, it is notable that recent work has increasingly focused upon the socio-linguistic interest of these texts in their cultural contexts, rather than more narrowly linguistic analysis. Consequently, it has seemed of greater value to attempt to sketch the key areas of focus and to try to detail the core evidence, since others have already explored the linguistic and graphic features in greater detail than is possible here. The argument of this presentation is twofold: firstly, without a more systematic, inclusive, and comprehensive collection and presentation of all the relevant texts from the island, including both Greek and non-Greek material from the seventh to fourth centuries BCE, it will remain extremely difficult to reach any firm conclusions, or indeed for the wider scholarly community to engage with this material in depth; secondly, if there has been a trend visible in recent scholarship beyond the increased emphasis upon socio-linguistics, it is a clear tendency to note and indeed emphasise the points of linguistic similarity and contact between the Sicilian languages, not only in the eastern and central parts of the island, but between Sikel and Elymian also. The question therefore deserves to be asked, whether the historiographic tradition has been overly influential in shaping the outlines of the linguistic analysis and in maintaining what may very well be excessively artificial lines of division. 


\section{$\begin{array}{llllllllllll}\mathbf{B} & \mathbf{I} & \mathbf{B} & \mathbf{L} & \mathbf{I} & \mathbf{O} & \mathbf{G} & \mathbf{R} & \mathbf{A} & \mathbf{P} & \mathbf{H} & \mathbf{Y}\end{array}$}

Agostiniani 1973: L. Agostiniani, "Per una definizione del materiale epigrafico anellenico di Sicilia”, SE 41, 1973, 388-395.

Agostiniani 1977: L. Agostiniani, Iscrizioni anelleniche di Sicilia. I. Le iscrizioni elime, Firenze 1977.

Agostiniani 1990: L. Agostiniani, "La lingua degli Elimi: per uno stato della questione", in: G. Nenci (ed.), Gli Elimi e l'area elima fino all'inizio della prima guerra punica: atti del seminario di studi, Palermo 1990, 345-368.

Agostiniani 1992: L. Agostiniani, "Les parlers indigènes de la Sicile pregrecque”, Lalies 11, 1992, 125-157.

Agostiniani 2006: L. Agostiniani, "Epigrafia e lingua elime: un bilancio", in: Guerra e Pace in Sicilia e nel Mediterraneo Antico (VIII-III sec. a.C.): Arti, Prassi e Teoria della Pace e della Guerra, Pisa 2006, 683-688.

Agostiniani 2009a: L. Agostiniani, "L'iscrizione della porta urbica del Mendolito", in: A. Ancillotti and A. Calderini (eds.), La città italica. Atti del II convegno internazionale sugli antichi Umbri, Gubbio, 25-27 settembre 2003, Perugia 2009, 35-52.

Agostiniani 2009b: L. Agostiniani, "Formule onomastiche binomie nelle epigrafi anelleniche di Sicilia", in: P. Poccetti (ed.), Lonomastica dell'Italia antica. Aspetti linguistici, storici, culturali, tipologici e classificatori, Rome 2009, 49-57.

Agostiniani 2012: L. Agostiniani, “Alfabetizzazione della Sicilia pregreca”, Aristonothos 4, 2012, 139-164.

Agostiniani and Albanese Procelli 2016: L. Agostiniani and R. M. Albanese Procelli, "La tomba Est 31 di Montagna di Marzo (Enna)", Kokalos 52/1, 2016, 17-50.

Agostiniani and Cordano 2002: L. Agostiniani and F. Cordano, "L'ambiente siculo", in: F. Cordano and M. di Salvatore (eds.), Il Guerriero di Castiglione di Ragusa: Greci e Siculi nella Sicilia sud-orientale, Atti del seminario - Milano, 15 maggio 2000, Rome 2002, 77-89.

Agostiniani and Prosdocimi 1976: L. Agostiniani and A. L. Prosdocimi, "Lingue e dialetti della Sicilia antica", Kokalos 22-23/1, 1976, 215-260.

Albanese Procelli 2003: R. M. Albanese Procelli, Sicani, Siculi, Elimi, Milan 2003.

Ampolo 2012: C. Ampolo, "Compresenza di ethne e culture diverse nella Sicilia occidentale. Per una nuova prospettiva storica", Aristonothos 12, 2012, 15-57.

Antonaccio 1999: C. M. Antonaccio, “An inscribed stele from archaic Morgantina”, Kadmos 38, 1999, 87-96.

Antonaccio and Neils 1995: C. Antonaccio and J. Neils, "A new graffito from archaic Morgantina", ZPE 105, 1995, 261-277.

Biondi 1992: L. Biondi, "Nuovi graffiti elimi", in: Atti delle giornate internazionali di studi sullarea elima (Gibellina, 15-22 settembre 1991), vol.1, Pisa 1992, 111-127.

Biondi 1993: L. Biondi, "Recenti rinvenimenti epigrafici da Segesta (Grotta Vanella) ed Entella", SE 58, 1993, 339-351. 
Biondi 1995: L. Biondi, “Iscrizioni elime”, AnnPisa. Classe di Lettere e Filosofia, ser.3, 25/4, 1995, 1179-1182.

Biondi 1997: L. Biondi, "Nuovi frammenti ceramici graffiti da Segesta", in: Atti delle seconde giornate internazionali di studi sullarea elima (Gibellina, 22-26 ottobre 1994), vol. 1, Pisa 1997, 141-162.

Biondi 1998: L. Biondi, “Frammenti ceramici iscritti da Segesta”, SE 62, 1998, 366-375.

Brugnone 1993: A. Brugnone, "Pesi da telaio", in: Di terra in terra. Nuove scoperte archeologiche nella provincia di Palermo, Palermo 1993, 53-60.

Bugnone 1995: A. Brugnone, "Gli alfabeti arcaici delle poleis Siceliote e l'introduzione dell'alfabeto milesio", AnnPisa. Classe di Lettere e Filosofia, ser.3, 25/4, 1995, 1297-1327.

Calascibetta 1990: A. Calascibetta, "Un graffito elimo da Monte Castellazzo di Poggioreale", AnnPisa. Classe di Lettere e Filosofia, ser.3, 20/1, 1990, 19-22.

Camerata Scovazzo 1988-1989: R. Camerata Scovazzo, "Studi e ricerche a Segesta: la ricostruzione della forma urbana”, in: G. Nenci (ed.), Gli Elimi e l'area elima fino all'inizio della prima guerra punica. Atti del seminario di studi, Palermo - Contessa Entellina, 25-28 maggio 1989, Palermo 1989, 259-270.

Cordano 1993: F. Cordano, “Coppe ioniche usate dai Siculi”, Bolletino d'Arte 80-81, 1993, 155 158.

Cordano 1999: F Cordano, "Iscrizioni dal territorio di Palagonia e Mineo (Catania)", in: XI Congresso Internazionale di Epigrafia Greca e Latina (Roma, 18-24 settembre 1997). Atti, vol.1, Rome 1999, 679-685.

Cordano 2002: F. Cordano, "Le identità di Siculo in età arcaica sulla base delle testimonianze epigrafiche”, in: L. Moscati Castelnuovo (ed.), Identità e prassi storica nel mediterraneo greco, Milan 2002, 115-135.

Cordano 2012: F. Cordano, "Iscrizioni monumentali dei Siculi", Aristonothos 4, 2012, 165-184.

Crevatin 1975: F. Crevatin, "Nuove iscrizioni pre-greche provenienti dalla Sicilia", Quaderni di storia antica e di epigrafia (Universita di Trieste) 1, 1975, 39-52.

Cultraro 2004: M. Cultraro, "Funzione e destinazione delle tegole con iscrizioni anelleniche: nuove e vecchi dati dal Mendolito di Adrano (Catania)", SE 70, 2004, 229-251.

Cusumano 2006: N. Cusumano, “Siculi”, in: P. Anello, G. Martorana, and R. Sammartano (eds.), Ethne e religioni nella Sicilia antica, Rome 2005, 121-146.

De Cesare 2009: M. de Cesare, "Lo scarico di Grotta Vanella a Segesta: revisione di un problema", in: S. Fortunelli and C. Masseria (eds.), Ceramica attica da santuari della Grecia, della Ionia e dell'Italia. Atti Convegno Internazionale, Perugia, 14-17 marzo 2007, Venosa 2009, 639-656.

De Vido 2006: S. de Vido, “Gli Elimi”, in: P. Anello, G. Martorana, and R. Sammartano (eds.), Ethne e religioni nella Sicilia antica, Rome 2006, 147-180.

Ferreri 2012: G. Ferreri, “Monte d'Oro di Montelepre. La necropoli di Manico di Quarara. Nuovi dati", in: C. Ampolo (ed.), Sicilia occidentale. Studi, rassegne, ricerche, Pisa 2012, 251-259.

Hurter 2008: S. M. Hurter, Die Didrachmenprägung von Segesta, Bern 2008.

Isler 2000: H. P. Isler, “Monte Iato: Scavi 1995-1997”, in: Terze giornate internazionali di studi sull'area elima, vol.2, Pisa 2000, 715-729.

Lejeune 1970: M. Lejeune, “Observations sur l'épigraphie élyme”, REL 47, 1970, 133-183.

Lejeune 1990a: M. Lejeune, "Notes de linguistique italique”. REL 68, 1990, 28-29. 
Jonathan Prag

Lejeune 1990b: M. Lejeune, “Le problème de l'élyme”, in: G. Nenci (ed.), Gli Elimi e l’area elima fino all'inizio della prima guerra punica: atti del seminario di studi, Palermo 1990, 339343.

Libertini 1923: G. Libertini, "Piccolo bronzo barbarico con breve iscrizione sicula", RIGI 7/3-4, 1923, 59-61.

Lyons 1996: C. Lyons, Morgantina Studies V. The Archaic Cemeteries, Princeton 1996.

MacDonald 1998: M. C. A. MacDonald, "Some reflections on epigraphy and ethnicity in the Roman Near East", Mediterranean Archaeology 11, 1998, 177-190.

Manganaro 1961: G. Manganaro, "Iscrizioni di Adrano in alfabeto siculo", Archeologia Classica 13, 1961, 106-112.

Manganaro 1965: G. Manganaro, "Per la storia dei culti in Sicilia", PP 20, 1965, 163-178.

Manganaro 1999: G. Manganaro, Sikelika: Studi di antichità e di epigrafia della Sicilia greca, Pisa 1999.

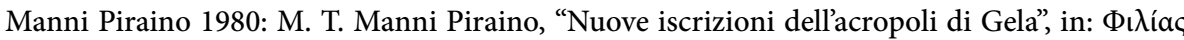

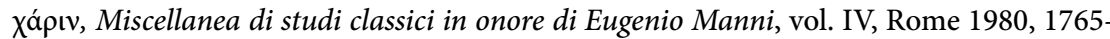
1832.

Marchesini 1998: S. Marchesini, "Il segno И in Elimo: una nuova proposta", AnnPisa. Classe di Lettere e Filosofia, ser.4, 3/1-2, 1998, 289-301.

Marchesini 2012: S. Marchesini, “The Elymian language”, in: O. Tribulato (ed.), Language and Linguistic Contact in Ancient Sicily, Cambridge 2012, 95-114.

Mussinano 1970: L. Mussinano, “Iscrizioni da Montagna di Marzo”, Kokalos 16, 1970, 166-183.

Nenci 1990: G. Nenci, "Iscrizioni elime, greche e latine”, AnnPisa. Classe di Lettere e Filosofia, ser.3, 20/2-3, 1990, 547-552.

Orsi 1900: P. Orsi, “Frammenti epigrafici sicelioti”, Rivista di storia antica 5, 1900, 39-66.

Paino 1958: E. Paino, "Nuova iscrizione sicula", Kokalos 4, 1958, 163-168.

Pancucci 2006: D. Pancucci, "I Sicani”, in: P. Anello, G. Martorana, and R. Sammartano (eds.), Ethne e Religioni nella Sicilia Antica, Rome 2006, 107-120.

Pelagatti 1976: P. Pelagatti, "L'attività della Soprintendenza alle Antichità della Sicilia Orientale. Parte I", Kokalos 22-23/2, 1976, 519-550.

Poccetti 2012: P. Poccetti, "Language relations in Sicily. Evidence for the speech of the $\Sigma$ ikavoi,

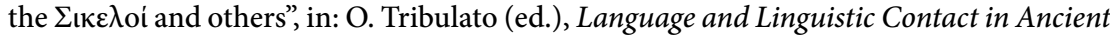
Sicily, Cambridge 2012, 49-94.

Prag 2013: J. R. W. Prag, "Sicilian identity in the Hellenistic and Roman periods: epigraphic considerations", in: P. Martzavou and N. Papazarkadas (eds.), Epigraphical Approaches to the Post-Classical Polis. Fourth Century BC to Second Century AD, Oxford 2013, 37-53.

Rutter 2013: N. K. Rutter, "Silvia Hurter's Segesta: Coins and History in western Sicily", Schweizerische Numismatische Rundschau 92, 2013, 5-18.

Rutter 2016: N. K. Rutter, "Coins in a 'Home Away from Home': the case of Sicily", in: J. Bintliff and N. K. Rutter (eds.), The Archaeology of Greece and Rome: Studies in Honour of Anthony Snodgrass, Edinburgh 2016, 289-313.

Sammartano 1998: R. Sammartano, Origines gentium Siciliae: Ellanico, Antioco, Tucidide, Rome 1998.

Schmoll 1958: U. Schmoll, Die vorgriechischen Sprachen siziliens, Wiesbaden 1958.

Simkin 2012: O. Simkin, "Coins and Language in Ancient Sicily", in: O. Tribulato (ed.), Language and Linguistic Contact in Ancient Sicily, Cambridge 2012, 162-187. 
Tribulato 2015: O. Tribulato, "Interferenza grafemica ed interferenza linguistica nella Sicilia antica", in: Contatti di lingue - contatti di scritture: Multilinguismo e multigrafismo dal Vicino Oriente antico alla Cina contemporanea, Venezia 2015, 59-83.

Tribulato 2017: O. Tribulato, "Learning to write in indigenous Sicily: A new abecedary from the necropolis of Manico di Quarara (Montelepre, south-west of Palermo)", ZPE 201, 2017, 117-122.

Whatmough 1933: J. Whatmough, The Pre-Italic Dialects of Italy. Volume II containing Part III. The Raetic, Lepontic, Gallic, East-Italic, Messapic and Sicel Inscriptions, London 1933. 